\title{
THE USE OF CARBON AND OXYGEN STABLE ISOTOPES IN THE STUDY OF GLOBAL PALAEOCEANOGRAPHIC CHANGES: EXAMPLES FROM THE CRETACEOUS SEDIMENT ROCKS OF WESTERN GREECE*
}

\author{
V. Karakitsios', H. Tsikos ${ }^{2}$, K. Agiadi - Katsiaouni', \\ S. Dermitzoglou ${ }^{1} \&$ E. Chatziharalambous ${ }^{1}$ \\ ${ }^{1}$ National \& Kapodistrian University of Athens, Faculty of Geology \& Geoenvironment Department of \\ Historical Geology \& Paleontology, Panepistimioupolis Zografou \\ vkarak@geol.uoa.gr, kagiadi@geol.uoa.gr \\ ${ }^{2}$ Department of Geology, Rhodes University, Grahamstown 6140, South Africa, h.tsikos@ru.ac.za
}

\begin{abstract}
In the present paper we examine the use of carbon and oxygen stable isotopes in the study of global palaeoceanographic changes, with special reference to the oceanic anoxic events (OAEs). The analysis of stable isotopes was applied to the examination of Cretaceous sediments from the lonian and Pindos zones of Western Greece. In the lonian zone the carbon and oxygen stable isotopes, combined with biostratigraphic data, record the palaeoenvironmental change corresponding to the anoxic events Bonarelli (Cenomanian/Turonian, OAE2) and Paquier (Lower Albian, OAE1b). In the Pindos zone, within the Cretaceous sediments, we observed two organic-carbon-rich levels. According to the biostratigraphic and isotopic analysis, the first level corresponds to an OAE of Santonian age. This local oceanic anoxic event is described for the first time. The second level, Aptian - Albian age, possibly correlates to either the Paquier event (OAE1b) or the Selli event (OAE1a), which in Greece were until now known only in the lonian zone.
\end{abstract}

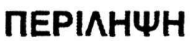

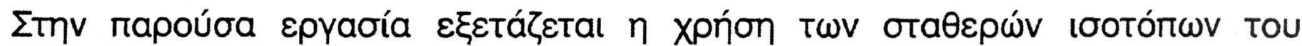

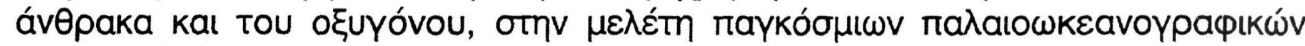

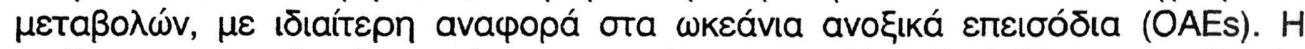

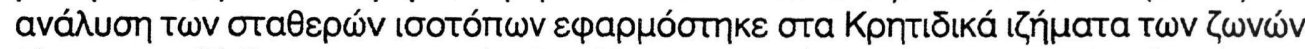

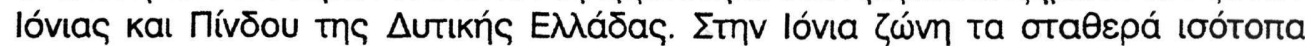

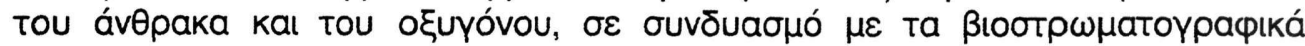

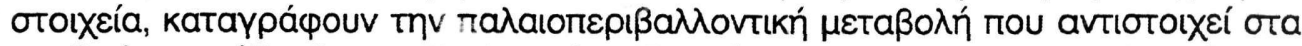

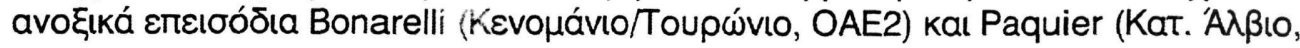

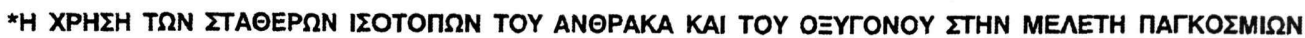

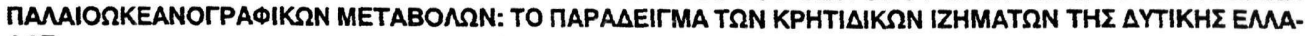
$\triangle \mathrm{A \Sigma}$

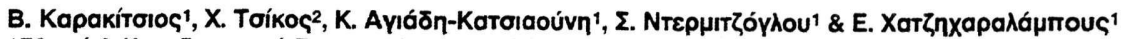

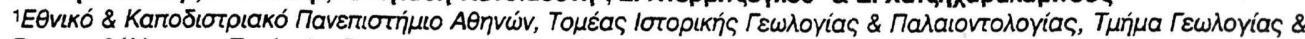

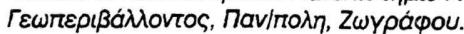

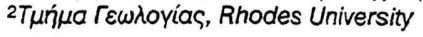




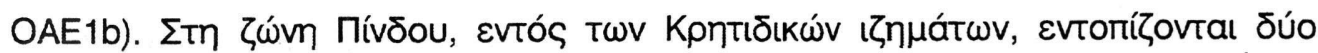

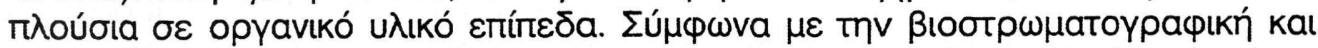

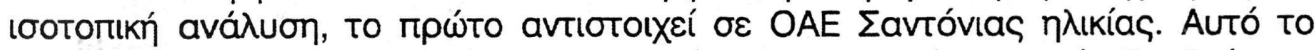

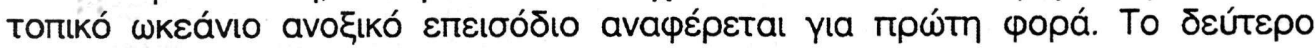

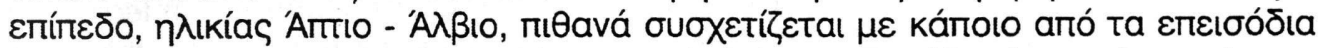

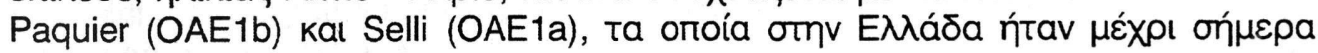

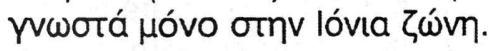

\section{Introduction}

The earth of the Mesozoic era is widely known as the "greenhouse world". During this era, there have been many short periods of time when the global climate changed rapidly, probably due to the dissociation, release and oxidation of gas hydrates from continental - margin sites and the consequent equally rapid global warming from the input of greenhouse gases, particularly methane (Jenkyns, 2003). The methane released from these gas hydrates was almost instantly oxidized to carbon dioxide, which was furthermore dispersed into the oceans and the atmosphere, raising the global temperature by several degrees. These phenomena are referred to as Oceanic Anoxic Events (OAEs) and are known to have occurred many times during the earth's history. The most important of these events are the Paleocene - Eocene thermal maximum, the Bonarelli event (Cenomanian - Turonian), the Paquier event (Lower Albian), the Selli event (Aptian), and the early Toarcian OAE.

The main characteristics of these short periods are high levels of atmospheric and oceanic $\mathrm{CO}_{2}$, almost complete absence of the permafrost, decreased thermal grades from the equator towards the poles, and increased temperature in the oceans. In addition, the Oceanic Anoxic Events are characterized by carbon and oxygen stable isotope excursions just before and during the events, which are recorded in many different marine environments (Jenkyns, 2003).

The global oceanic anoxic events are associated with the deposition of black shale horizons, which have been deposited during very short periods of time. These deposits consist of organiccarbon-rich sediments, which represent major disturbances of the oceanic system and carbon cycle. There are three primary triggers of organic-carbon-rich sediment deposition (Harris, 2005), namely: (1) reduced oxygen levels which do not allow the degradation of organic matter (Demaison \& Moore, 1980, Tyson, 1987), (2) organic productivity in the photic zone, usually stimulated by high nutrient flux, that overwhelm the oxidizing capacity of the water body (Suess et al., 1987, Pedersen \& Calvert, 1990), and (3) slow sedimentation of clastics or carbonates that would otherwise dilute the organic matter (Creaney \& Passey, 1993). According to Tyson $(2001,2005)$ when the sedimentation rate is generally low, a relative increase serves to isolate organic matter from the oxidizing water and enhance organiccarbon content. Reversely at high sedimentation rates, the relative increase simply dilutes the organic carbon. The relative significance of these three factors is still greatly debated.

Because not all the organic-carbonrich black shale horizons are caused by global oceanic anoxic events, the analysis of carbon and oxygen stable isotopes is essential to the recognition of genuine OAEs. Indeed a main char- 
acteristic of OAEs is the abrupt negative excursions in carbon and oxygen isotopic ratios. By analyzing the isotopic content of sediment samples from a continuous section comprising the pre-, syn- and post-deposition of the organiccarbon-rich horizon, we are able to detect excursions of the $\delta^{13} \mathrm{C}$, which are indicative of an OAE.

The carbon and oxygen stable isotopic ratios are calculated by comparison with the standard PDB belemnite $\left({ }^{13} \mathrm{C} /{ }^{12} \mathrm{C}\right.$ and ${ }^{18} \mathrm{O} /{ }^{16} \mathrm{O}$ respectively in belemnites from S. Carolina U.S.A.) or other new local standard, according to the formula: $\delta=\{[$ Rsample- Rstandard $] /$ Rstandard $\}^{\star} 1000$, where $R$ is the molar equivalent of ${ }^{13} \mathrm{C} /{ }^{12} \mathrm{C}$ or ${ }^{18} \mathrm{O} /{ }^{16} \mathrm{O}$ for $\mathrm{CO}_{2}$ analysis. The $\delta^{18} \mathrm{O}$ values, in biogenic marine carbonates, reflect both the temperature and the ${ }^{18} \mathrm{O} /{ }^{16} \mathrm{O}$ ratio of the water in which these carbonates formed (McCrea, 1950, Urey et al., 1951). The $\delta^{13} \mathrm{C}$ values in marine carbonates reflect the ${ }^{13} \mathrm{C} /{ }^{12} \mathrm{C}$ ratio of $\mathrm{CO}_{2}$ dissolved in deep ocean water, which in turn depends on the source of carbon in the $\mathrm{CO}_{2}$. Carbon dioxide enters in the ocean by interchange with the atmosphere, and it is also generated by the decay of organic matter both on land and in the ocean water. The later is relatively depleted of ${ }^{13} \mathrm{C}$ because organisms preferentially incorporate ${ }^{12} \mathrm{C}$. Thus the water runoff from the continents is organic-rich and with low ${ }^{13} \mathrm{C} /{ }^{12} \mathrm{C}$. As a result a negative excursion of $\delta^{13} \mathrm{C}$ could indicate an increase in water runoff from the continents. Another factor which influences the $\delta^{13} \mathrm{C}$ content of ocean water is the residence time of deepwater masses in the ocean. Water bodies that have remained in the bottom of the ocean for a long period of time are also depleted of ${ }^{13} \mathrm{C}$, due to the oxidation of low $\delta^{13} \mathrm{C}$ marine organic matter that sinks from the surface. Respiration by bottom-dwelling organisms also

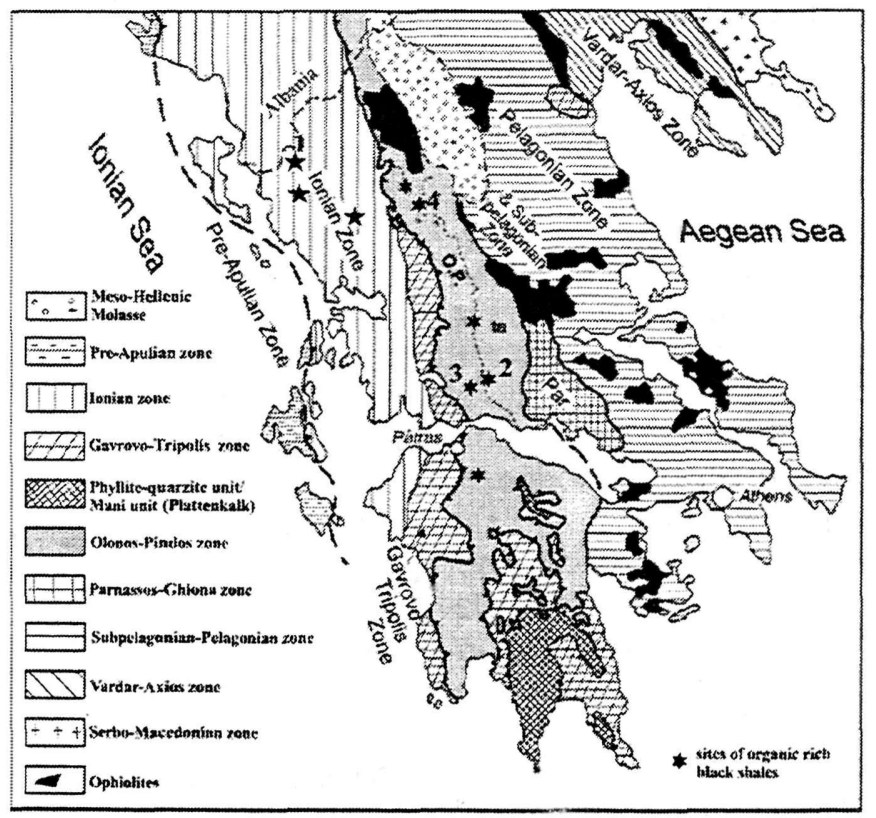

Fig. 1. Simplified geologic map of Greece. Noted with asterisk are the sites of organic rich black shales. 1: Gotzikas section, 2: Proussos section, 3: Panaetolikon section, 4: Kalarites section. 
apparently causes a decrease in $\delta^{13} \mathrm{C}$ of deep bottom waters. Additionally negative excursions of $\delta^{13} \mathrm{C}$ can be attributed to decreased primary productivity of photosynthesizing marine organisms. On the other hand a positive $\delta^{13} \mathrm{C}$ excursion corresponds to increased primary productivity, and increased sedimentation rate, which permits the renewal of the deep-water masses.

In this paper, we present up to date results of our studies on integrated chemostratigraphy and biostratigraphy of Cretaceous pelagic carbonate successions and associated organic carbon rich sediments of Western Greece (Ionian and Pindos zones, Fig. 1).

\section{Regional Geological Context \\ 2.1. Ionian zone}

The lonian zone (W. Greece) belongs to the External Hellenides' domain, which corresponds to the southern passive continental margin of the Neotethys ocean (Laubscher \& Bernoulli, 1977, Karakitsios, 1992, 1995). It comprises sedimentary rocks ranging from Triassic evaporites, and associated breccias, to the Jurassic - Eocene carbonates and lesser cherts and shales, which are followed by the Oligocene flysch (Fig. 2). During the Early Lias, the present part of western Greece was covered by an extensive carbonate platform (Bernoulli \& Renz, 1970, Karakitsios, 1992, 1995). The contemporaneous shallow-water Pantokrator limestones represent the pre-rift sequence of the lonian domain (Karakitsios, 1990, 1992). During the Pliensbachian extensional stresses associated with the opening of the Neotethys brought about the formation of the Ionian Basin (Karakitsios, 1992, 1995). This Basin became an area of persistent syn-sedimentary faulting and subsidence.
The syn-rift sequence began with the deposition of the Siniais Limestones and their lateral equivalent, the Louros Limestones (Karakitsios \& TsailaMonopolis, 1988, Dommergues et al., 2002). These formations record regional subsidence followed by internal synrift differentiation of the Ionian Basin into smaller palaeogeographic units and evaporitic base halokinesis, which was recorded by the prismatic wedges of the syn-rift formations, and include the Louros Limestones, the Ammonitico Rosso or Lower Posidonia Beds, the Limestones with Filaments and the Upper Posidonia Beds (Karakitsios et al., 1988; Karakitsios, 1995). The post-rift sequence in the lonian Basin is defined by an unconformity (Early Berriasian) at the base of the Vigla Limestone Formation, whose deposition was relatively uniform across the Basin (Karakitsios, 1990; Karakitsios \& Koletti, 1992). The particular geometry of the restricted sub-basins that were formed during the syn-rift and post-rift periods may have favored increased organic matter burial during the early Toarcian, late Callovian - Tithonian (Posidonia Beds) and Aptian - Cenomanian (Vigla Shale Member) (Karakitsios, 1995, Rigakis \& Karakitsios, 1998). The main orogenic movements in the lonian zone took place at the end of the Burdigalian. The geologic evolution of the lonian basin is an example of inversion tectonics of a basin with evaporitic basement (Karakitsios, 1995).

\subsection{Pindos zone}

The Pindos zone is also part of the External Hellenides' domain, and appears in Western Greece as a series of stacked and imbricated, north-southtrending thust sheets, which were emplaced during the Tertiary Alpine 


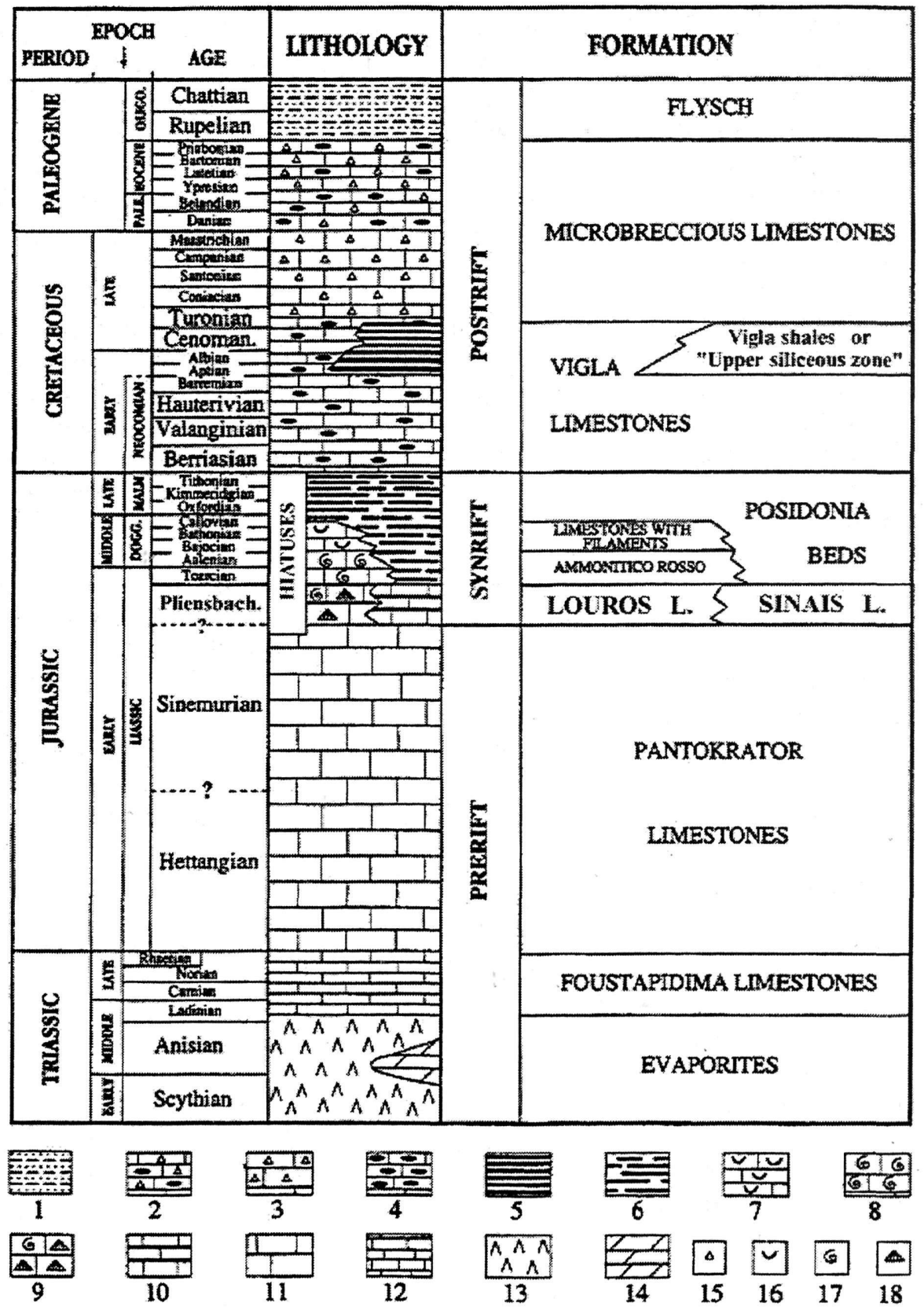

Fig. 2. Representative stratigraphic column of the lonian zone (Karakitsios, 1995). 1: pelites and sandstones, 2: cherty limestones with clastic material, 3: pelagic limestones with clastic metarial, 4: pelagic cherty limestones, 5: cherty beds with green \& red clay, sometimes shaly, 6: pelagic limestones, marls, and siliceous argillites, 7: pelagic limestones with thin-shelled bivalves, 8: pelagic, red, nodular limestones with ammonites (Ammonitico rosso), 9: pelagic limestones with small ammonites \& brachiopods, 10: pelagic limestones, 11: platform carbonates, 12: platy black limestones, 13: gypsum and salt, 14: dolomites, 15: breccia, 16: section of pelagic bivalve (filament), 17: ammonite, 18: brachiopod. 
Upper Maastrichtian

Maastrichtian
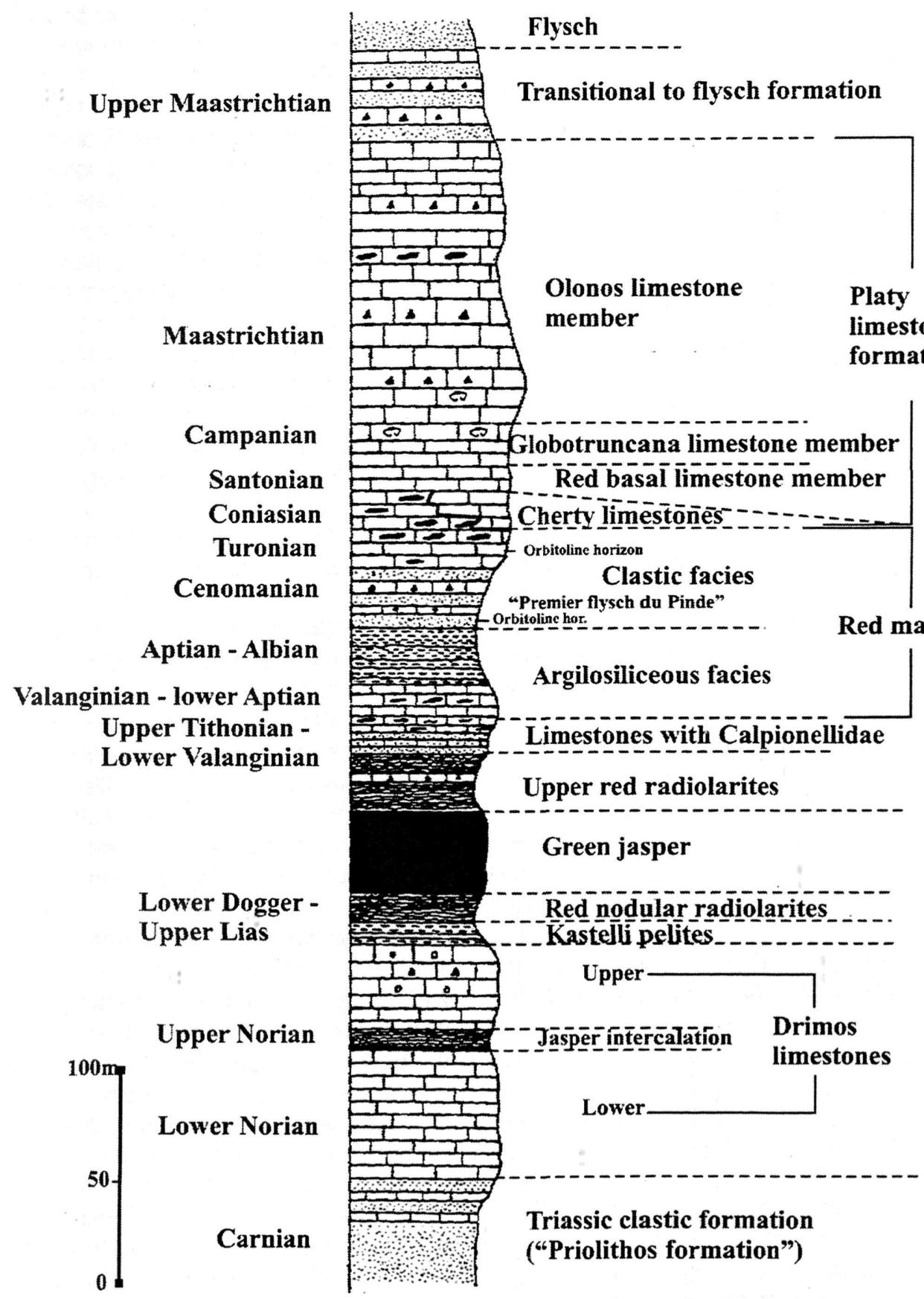

Fig. 3. Synthetic stratigraphic column of the Olonos - Pindos zone. 
orogeny (Fig. 3). The Pindos palaeogeographic domain is bordered to the east by the Parnassus-Ghiona zone and the Pelagonian zone, and to the west by the Gavrovo-Tripolis platform (Robertson et al., 1991).

From the major orogenic phases affecting the Hellenides, the Mesohellenic phase and the Neohellenic phase (latest Cretaceous - Tertiary) affected the development of the pelagic Pindos zone during the Cretaceous (Neumann \& Zacher, 2004).

The stratigraphic column of Pindos zone in Western Greece comprises basal Triassic clastic formations, followed by pelagic limestones and cherts (Norian - Liassic). Radiolarites s.l. are deposited throughout the Aalenian - base of Senonian interval, whilst platy pelagic limestones (with Globotrunacana spp.) appear during the Upper Cretaceous. Finally, there is a transitional formation ("couches de passage") between the siliceous-calcareous beds and the flysch deposition (Paleocene) (Fleury, 1980).

During the Early Cretaceous, ophiolites were emplaced onto the Pelagonian microcontinent situated east of the deepmarine siliceous Pindos basin (Huss et al., 1987). The true origin of these ophiolites and therefore the nature of the Pindos basin remains still a very controvertial subject. Some authors assume that the ophiolites partly originated from a Jurassic Pindos ocean (Clift \& Robertson, 1990), while others believe that an eastward origin is more likely (Stampfli, 2000). In any case, clastic deposition took place along the margins of the Pindos basin, during the Earliest Cretaceous, as a result of these orogenetic movements (Richter et al., 1996). Siliclastic lithologies of the Pindos Basin known as "Premier flysch du Pinde" (Fig. 3) are assumed to reflect these eohel- lenic and/or younger tectonic processes in the eastern zones (Aubouin, 1959, Richter et al., 1996).

At the end of the Campanian the neritic development of the Pelagonian and Parnassus-Ghiona zones ceased and all sectors of the carbonate-platform belt east of the Pindos basin were covered by a blanket of pelagic limestones, which are equivalent to those deposited in the Pindos basin (Fleury, 1980, Neumann \& Zacher, 2004). The Pindos zone resembled the western slope of this pelagic sea attached to the Gavrovo-Tripolis platform, which, in the latest Maastrichtian - Palaeogene, was invaded by siliclastic sediment commencing flysch deposition in the western Hellenides (Gonzalez-Bonorino, 1996).

\section{Methodology}

We collected hand-specimens approximately every 0,5 to $2 \mathrm{~m}$ along the sections where the black shale horizons were located. About $10 \mathrm{mg}$ from each sample were powdered after careful screening to avoid contamination from weathering surfaces, local intense silicification or secondary carbonate veining.

Powdered samples were analyzed for TOC and total carbonate contents, as well as bulk organic carbon and/or carbonate isotope ratios at the Departments of Earth Sciences and Archaeology, University of Oxford. Duplicate TOC analyses were obtained for all organic carbon-rich samples, using a Strohlein Coulomat 702 device. Rock-Eval pyrolysis data (S0, S1, S2 and Tmax values) for the same samples were quantified using a LECO THA 200 Thermolytic Analyzer at the University of Newcastle. The standard deviations of duplicate analyses for S2 and Tmax, expressed as percentages of the average value, are \pm 
$5 \%$ and $\pm 4 \%$ respectively.

For determinations of bulk organic carbon - isotope compositions, all TOC - rich samples were acidified with dilute $\mathrm{HCl}$ at ambient temperature to remove carbonate. Approximately 5-10mg of the dried carbonate-free residues were weighed in tinfoil cups and placed in a Europa Scientific Limited $\mathrm{CN}$ biological sample converter connected to a 20-20 stableisotope gas-ratio mass spectrometer. Carbon-isotope ratios were measured against a laboratory nylon standard, with a $\delta^{13} \mathrm{C}$ value of $-26.1 \pm 0.2 \%$. Analytical results are presented in \%० deviation from the VPDB (Vienna Pee Dee Belemnite) standard.

Carbonate $(\mathrm{C}, \mathrm{O})$ isotope ratios for all collected samples were determined on $\mathrm{CO}_{2}$ gas yielded after reaction with orthophosphoric acid at $90^{\circ} \mathrm{C}$, using a VG Isocarb device and Prism mass spectrometer. Normal corrections were applied and calibration to VPDB was preformed via our laboratory standard calibrated against NBS19 and Cambridge Carrara marble. Reproducibility of replicate analyses of standards was generally better than $0.1 \%$ o for both carbon and oxygen isotope ratios.

Complementary to the carbon and isotope analysis, palynofacies analysis and compound-specific isotope analysis was applied to our samples. These analyses have been completed as far as the Ionian zone samples are concerned (Karakitsios et al., 2004, Tsikos et al., 2004) and the Pindos zone samples are being examined at present.

Regarding the chronostratigraphic control, we have applied biostratigraphic analysis on thin sections and smear slides, so as to examine both foraminifera and calcareous nannofossils. The examination has been conducted at the Department of Earth Sciences 'Ardito
Desio' (University of Milan), and at the Department of Historical Geology and Paleontology (University of Athens).

\section{Results}

\subsection{Ionian Zone}

The organic-carbon-rich black shale horizons are located in the Vigla limestone formation, which has been examined thoroughly in the Gotzikas section (in the homonymous valley) south of the Tsamantas village (NW Epirus). Generally the Vigla limestone formation (Berriasian - Turonian) comprises a thick succession of thin-layered $(5-10 \mathrm{~cm})$, sublithographic, pelagic limestones, with abundant radiolarian and frequent cherty beds with radiolarian. In the upper part, this formation contains a series of organic-carbonrich marlstones and shales interbedded with limestone and cherty beds. This series now named Vigla shale member corresponds to the "Upper Siliceous Zone" of Albian - Cenomanian age (IGRSIFP, 1966). In the Gotzikas section the Vigla shale member comprises 27 decimeter-thick horizons of organic-matterrich calcareous mudstones and shales, within the partially silicified limestone beds (Fig. 4).

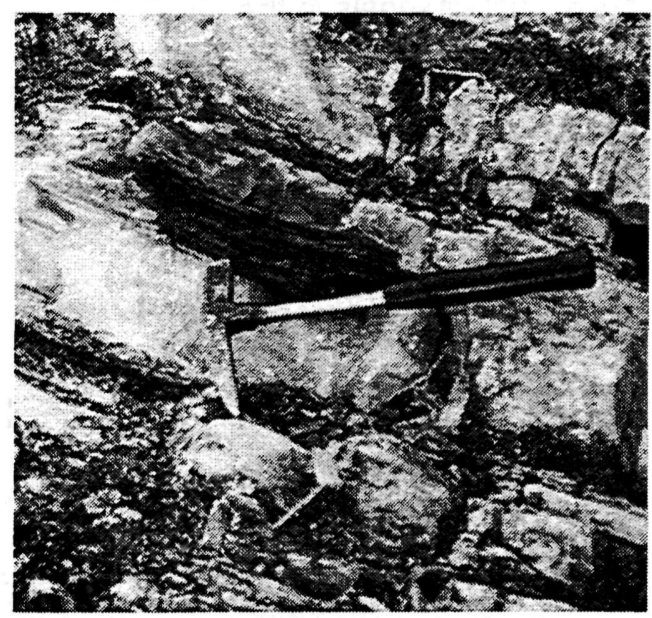

Fig. 4. A black shale horizon in the Gotzikas section (hammer for scale). 
Chemically, within the organic-carbonbearing marls (TOC content: 1 to 6 wt\%, bulk $\delta^{13}$ CTOC: 27.2 to $-24.2 \%$, and hydrogen index: 170 to $450 \mathrm{mg} / \mathrm{g}$ ), only two horizons display clear characteristics of true black-shale deposits, i.e. higher TOC content $(44.5 \mathrm{wt} \%$ in the upper and $28.9 \mathrm{wt} \%$ in the lower horizon) and much higher $\delta^{13} \mathrm{CTOC}$ values $(-22.2$ and $-22.1 \%$ respectively) than the surrounding beds (Fig. 5). The rise in $\delta^{13} \mathrm{CTOC}$ of the lower horizon coincides with a respective, positive shift in bulk carbonate $\delta 13 \mathrm{C}$ values in limestone immediately below. On the contrary, the upper horizon did not give any bulk carbonate $\delta^{13} \mathrm{C}$ value, due to its particularly high TOC content $(44.5 \mathrm{wt} \%)$. The presence of the planktonic foraminiferal assemblage Rotalipora appenninica, Rotalipora cushmani in the $6 \mathrm{~m}$ of limestone immediately under, and of Praeglobotruncana gibba in the $5 \mathrm{~m}$ immediately over, the upper horizon, place this level to the Cenomanian - Turonian boundary interval (Fig. 6). Additionally, the presence of calcareous nannofossil Hayesites albiensis in the stratigraphic interval $3 \mathrm{~m}$ below and $10 \mathrm{~m}$ above the lower horizon, as well as that of calcareous nannofossil Eiffellithus turriseiffellii and planktonic foraminiferal Biticinella breggiensis, Planomalina buxtorfi, Rotalipora appenninica at the first 7-10 $\mathrm{m}$ above it, place the lower horizon to the Lower - Middle Albian time span (Fig. 6).

The causes for the sharp shifts in $\delta^{13} C T O C$ in the two horizons are diverse (Fig. 5). The predominance of hopanoids in apolar hydrocarbon fractions, and lesser 2-methyl-hopanoids indicate a substantial relative contribution of bacteria (in particular cyanobacteria). This observation is also true for other organic-carbon-rich marine deposits of the Cenomanian - Turonian interval, comprising the oceanic anoxic event (OAE2), also known as Bonarelli event (Tsikos et al., 2004; Karakitsios et al., 2004).

On the contrary, the relatively high bulk $\delta^{13} \mathrm{CTOC}$ value of the lower horizon is attributed to the predominance of isotopically heavy cyclic isoprenoids relative to steroids / hopanoids, which points to an episodic, sharp increase in the relative contribution of marine chemoautotrophic archaea to the organic matter, in

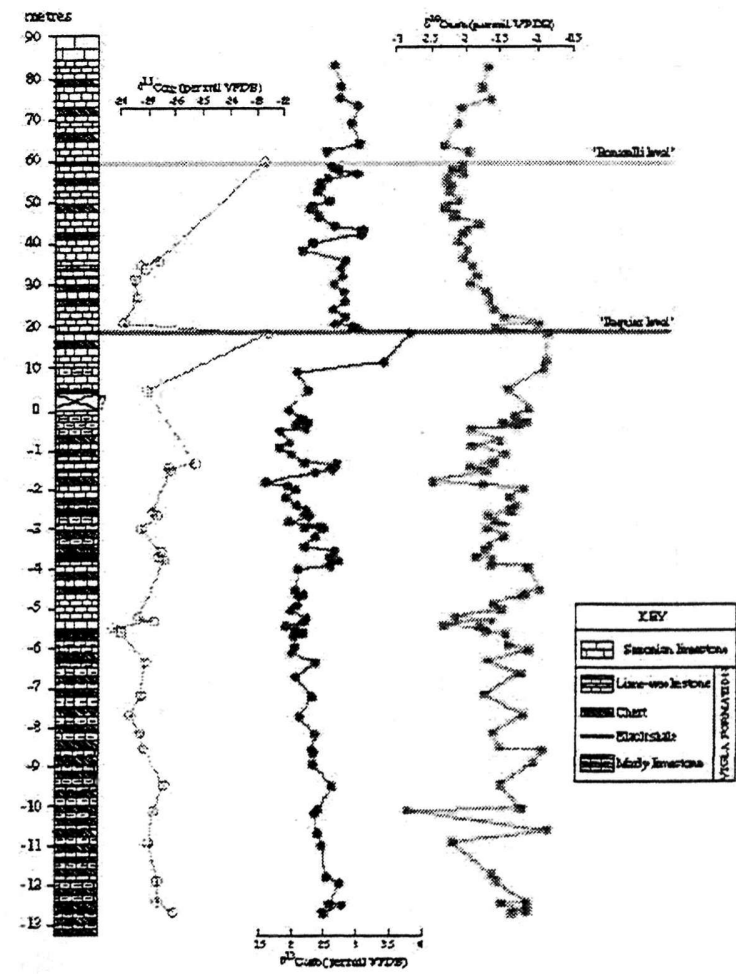

Fig. 5. Lithostratigraphic $\log$ and $\delta$ stable $(C, O)$ isotope profiles across the examined Vigla section in the Gotzikas locality, Ionian zone, NW Greece. Note the different scales for the section above and below the section gap. 


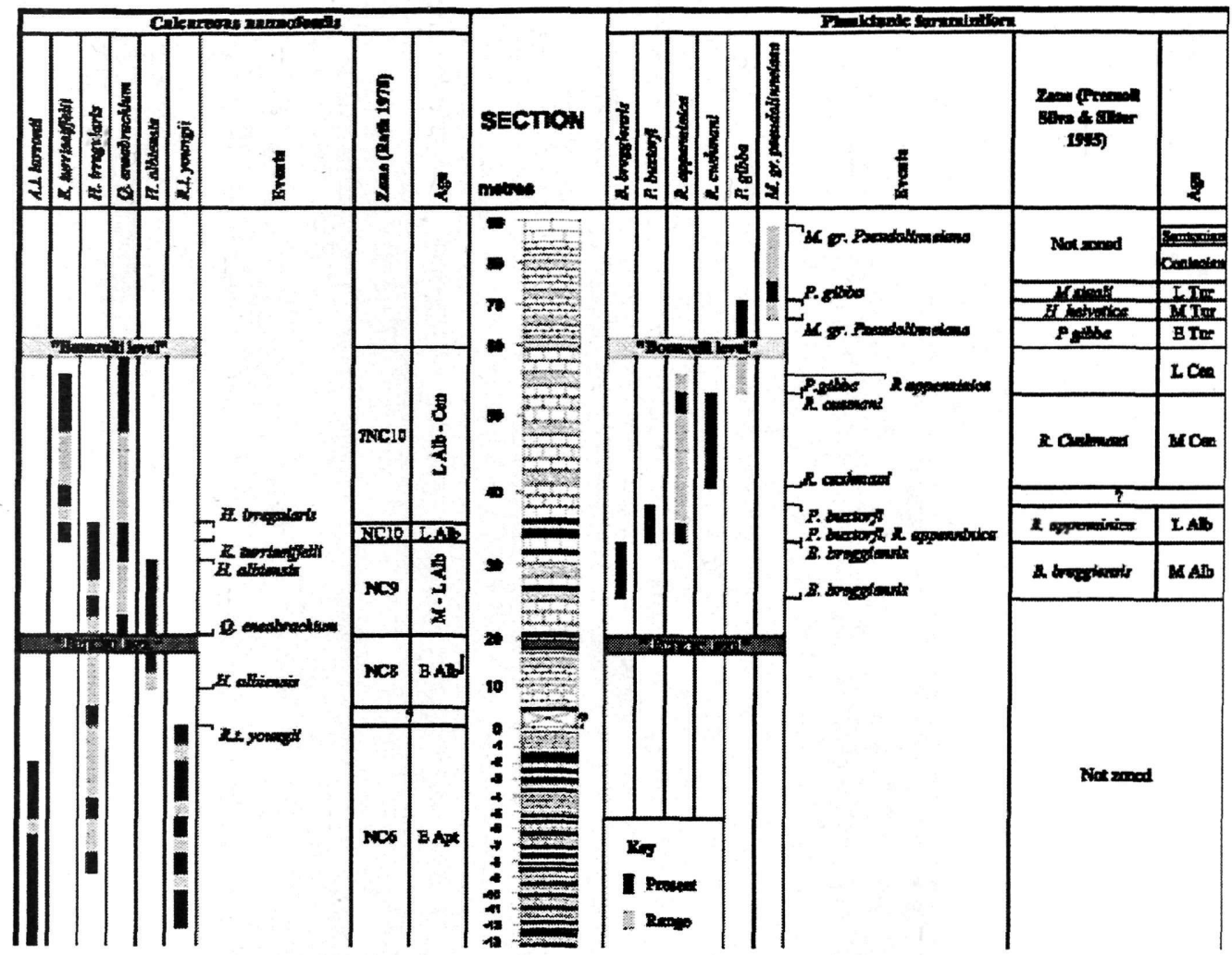

Fig. 6. Summary of biostratigraphic information for the Gotzikas section. Biostratigraphy is based on observed distribution of calcareous nannofossils and planktonic foraminifera.

addition to a primarily algal source.

As a result, it seems very likely that this horizon corresponds to the welldocumented Lower Albian oceanic anoxic event (OAE1b) or else "Paquier event" (Tsikos et al., 2004; Karakitsios et al., 2004), which is currently known to characterize only the Tethys - Atlantic regions (Tsikos et al., 2003).

\subsection{Pindos zone}

Black shale horizons were also observed in the pelagic Cretaceous formations of the Pindos zone. Particularly these were located in limestones, cherts and red marls of Aptian - Albian and Santonian age (Fig. 7). Limestones, marly limestones and cherts outcrop in the Proussos section, on the road from Karpenisi to the Proussos Monastery. The carbon and oxygen stable isotope analyses of samples, taken along this section, exhibit a distinctive negative excursion in the isotopic ratios, which is immediately followed by a positive excursion, just beneath the black shale anoxic horizon (Fig. 10). The presence of planktonic foraminifera Globotruncanita elevata and Marginotruncana gr. pseudolinneiana, in the black shale horizon, place this horizon in the upper part of the Dicarinella assymetrica biozone of Upper Santonian age. We therefore conclude that the above organic-carbon-rich black shale horizon probably corresponds to an oceanic anoxic event. This is the first time such an 
V. Karakitsios, H. Tsikos, K. Agiadi - Katsiaouni, S. Dermitzoglou \& E. Chatziharalambous

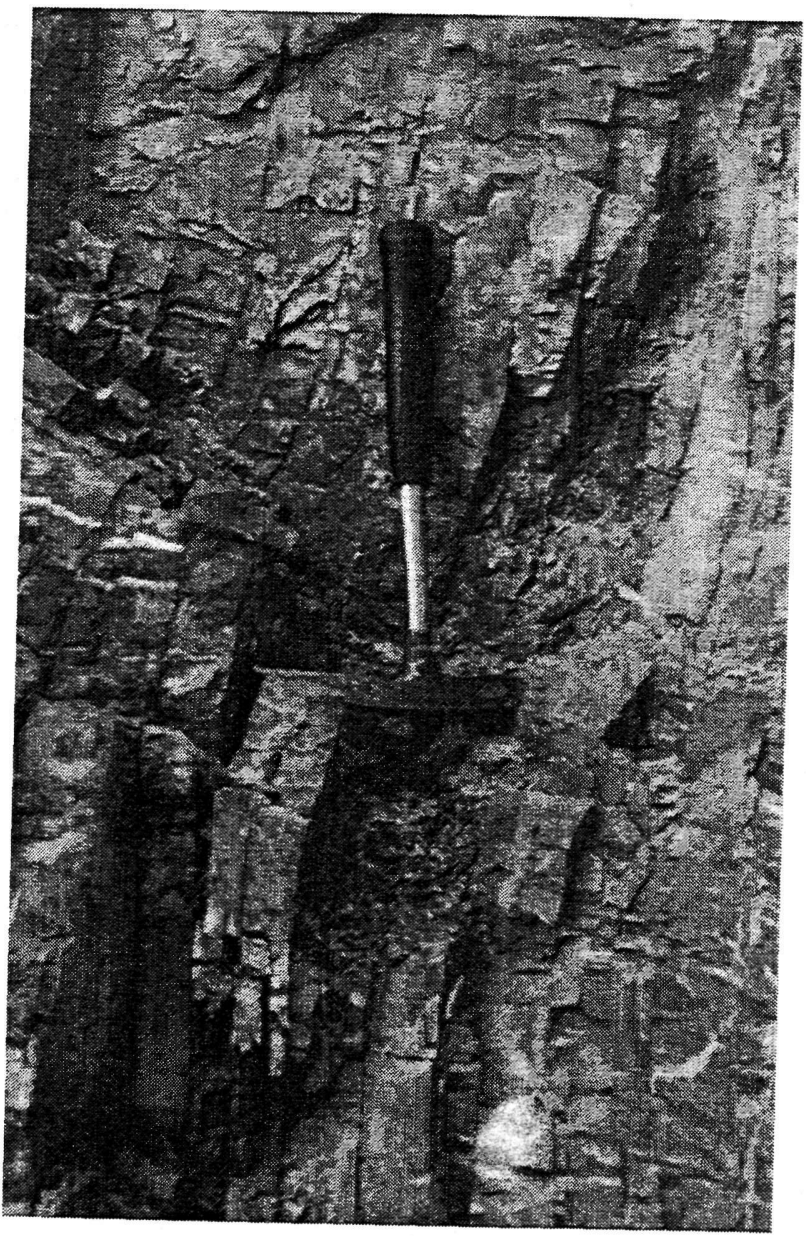

Fig. 7. A black shale horizon in the Santonian sediments of the Proussos section.

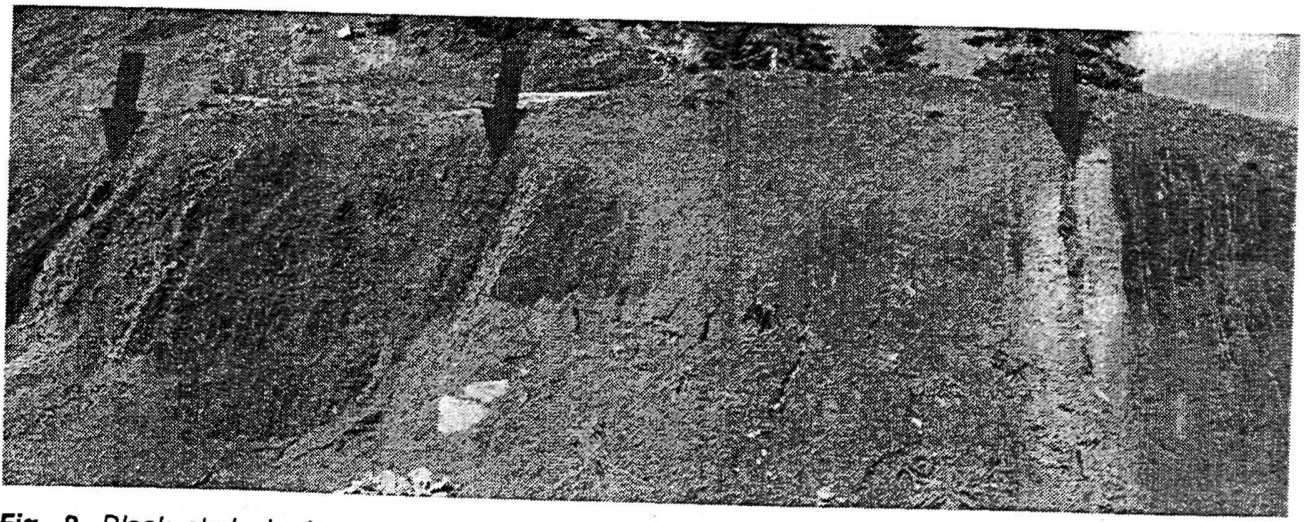

Fig. 8. Black shale horizons in the Panaetolikon section. This section corresponds to an up-fold. axis is placed between them). 


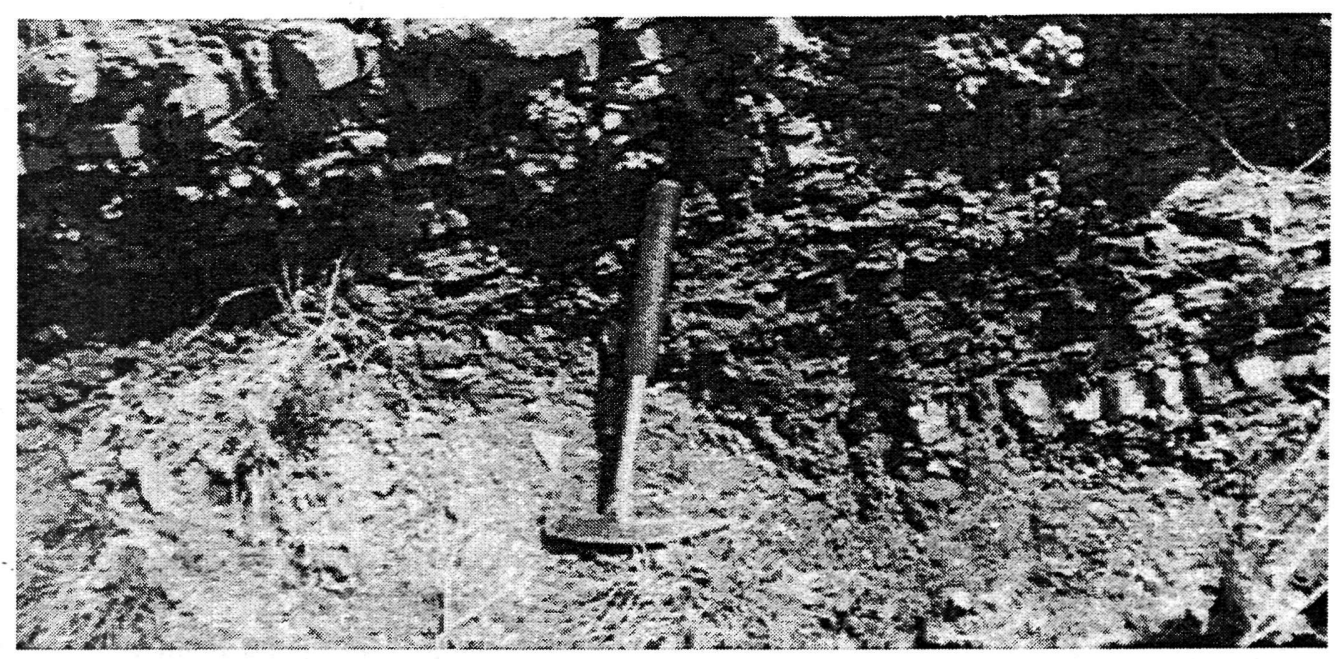

Fig. 9. The main black shale horizon in the Kalarites section.

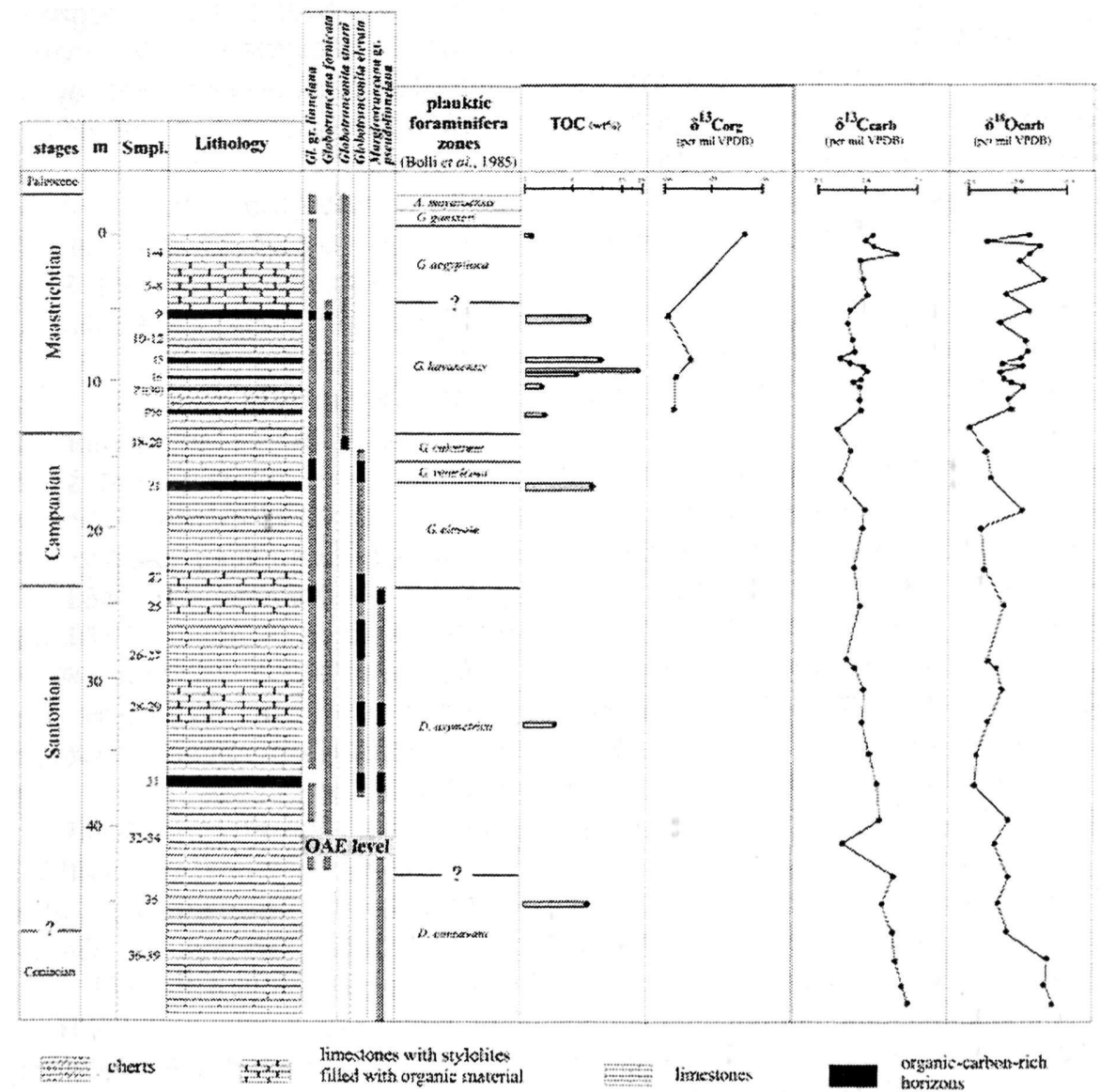

Fig. 10. Summary of biostratigraphic information for the Proussos section. Biostratigraphy is based on observed distribution of planktonic foraminifera. 
event is described, within the Cretaceous, but after the OAE3 (Coniasian-Santonian boundary), the identifying factor being the carbon and oxygen stable isotopic ratios anomaly.

Within the Pindos zone formations, in the sections Panaetolikon (Fig. 8) and Kalarites (Fig. 9) we have also identified organic-carbon-rich black shale horizons, which possibly correspond to the oceanic anoxic events of Aptian-Albian age. These horizons can be correlated to the ones formerly described in the lonian zone, as corresponding to the OAE 1b (Paquier Event), or to the OAE1a (Selli event), (Danelian et al., 2004).

\section{Conclusions}

The present research renders the use of carbon and oxygen stable isotopic analyses an important tool in the study of global palaeoceanographic change. Undoubtedly the field observation of black shale horizons is a first indication of the presence of an oceanic anoxic event. However, not all black shales correspond to global anoxic events. The fluctuation of $\delta^{13} \mathrm{C}$ and $\delta^{18} \mathrm{O}$ ratios in the ocean water through time, as recorded in the sediments deposited during this time, reflect the changes in the $\mathrm{CO}_{2}$ content in the oceans as well as in the atmosphere. These disturbances of the carbon cycle are considered to be the main cause of biologic, climatic and other environmental change, and are thus intimately connected to the Oceanic Anoxic Events. Consequently, only the identification of $\delta^{13} \mathrm{C}$ and $\delta^{18} \mathrm{O}$ ratio anomalies in complete geologic sections, accompanied by integrated stratigraphy, should be used to correctly identify Oceanic Anoxic Events.

In the Greek realm, the following Oceanic Anoxic Events have been so far identified:
- The Bonarelli Event (OAE2) at the Cenomanian - Turonian boundary interval of the Ionian zone formations, - The Paquier Event (OAE1b) of Lower Albian age, also in the lonian zone, - An Upper Santonian OAE in the Pindos zone formations, described for the first time herein.

- Additionaly, in the Aptian - Albian formations of the Pindos zone, we have identified anoxic black shale horizons, which probably correspond either to the well documented Paquier Event of Lower Albian age, or to the Selli event of Aptian age. Samples from complete sections covering this age span are currently under analysis, regarding the carbon and oxygen isotopic contents, in order to conclude whether they truly correspond to an oceanic anoxic event.

\section{Acknowledgements}

The project is co-funded by the European Social Fund and National Resources (EPEAEK II) PYTHAGORAS II.

\section{Bibliography}

Aubouin, J., 1959. Contribution a l'etude geologique de la Grece septentrionale: les confines de l'Epire et de la Thessalie, Annales Geologiques des Pays Helleniques, 1 : 1-483.

Bernoulli, D., \& Renz, O., 1970. Jurassic Carbonate Facies and New Ammonite Faunas from Western Greece, Eclogae Geologicae Helvetiae, 63: 573-607.

Clift, P.D., Robertson, A.H.F., 1990. Deep-water basins within the Mesozoic carbonate platform of Argolis, Greece, J. Geol. Soc. London, 47: 825-836.

Creaney, S., \& Passey, Q.R., 1993. Recurring patterns of total organic carbon and source rock quality within a sequence stratigraphic framework, 
American Association of Petroleum Geologists, Bulletin, 77: 386-401.

Danelian, T., Tsikos, H., Gardin, S., Baudin, F., Bellier, J.-P., Emmanuel, L., 2004. Global and regional palaeoceanographic changes as recorded in the mid-Cretaceous (Aptian-Albian) sequence of the Ionian zone (NW Greece), Journal of the Geological Society, London, 161, 703-709.

Demaison, G., \& Moore, G.T., 1980. Anoxic environments and oil source bed genesis, American Association of Petroleum Geologists, Bulletin, 64: 1179-1209.

Dommergues, J.-L., Karakitsios, V., Meister, C., Bonneau, M., 2002. New ammonite data about the earliest synrift deposits (Lower Jurassic) in the Ionian Zone of NW Greece (Epirus), Neues Jahrbuch fur Geologie und Palaeontologie, Abhandlungen, 223: 299-316.

Fleury, J.-J., 1980. Leszones de GevrovoTripolitza et du Pinde-Olonos (Grece Continentale et Peloponnese du Nord). Evolution d'une platforme et une bassin dans le cadre alpin, Soc. Geol. Nord, 4 : 1-651.

Gonzalez-Bonorino, Gi, 1996. Foreland sedimentation and plate interaction during closure of the Tethys ocean (Tertiary; Hellenides; western continental Greece), J. Sediment. Res., 66: 1148-1155.

Harris, N.B., 2005. Introduction, In: Harris, N.B., (ed.) The deposition of organic-carbon-rich sediments: models, mechanisms, and consequences, SEPM special publication No. 82, 1-5.

Huss, A., Gaitanakis, P., Neugebauer, J., 1987/88. Der Ammonotico Rosso und seine sedimentaere und ophiolithische Bedeckung bei Ano Fanari (Argolis, Griechenland) -
Tektonik einer obduzierten Melange und seines Unterlagers, Annales Geologique des Pays Hell., 33: 85112.

IGRS-IFP, 1966. Etude Geologique de L'Epire (Grece Nord-Occidentale), Paris, Technip Editions, 306 pp.

Jenkyns, H.C., (2003). Evidence for rapid climate change in the Mesozoic - Palaeogene greenhouse world, Phil. Trans. R. Soc. London A, 361: 1885-1916.

Karakitsios, V., 1990. Chronologie et geometrie de l'ouverture d'un bassin et de son inversion tectonique : le bassin ionien (Epire, Grece), Memoires Sciences de la Terre, Universite Pierre et Marie Curie, Paris, 91(4) : $310 \mathrm{pp}$.

Karakitsios, V., 1992. Ouverture et Inversion Tectonique du Bassin Ionien (Epire, Grece), Annales Geologiques de Pays Helleniques, $35: 85-318$.

Karakitsios, V., 1995. The influence of preexisting structure and halokinesis on organic matter preservation and thrust system evolution in the Ionian Basin, Northwestern Greece, American Association of Petroleum Geologists Bulletin, 79: 960-980.

Karakitsios, V., Danelian, T \& De Weverm, P., 1988. Datation par les radiolaires des Calcaires a Filaments, Schists a Posidonies superieurs et Calcaires de Vigla (zone ionienne, Epire, Grece) du Callovien au Tithonique terminal, Comptes Rendus de I'Academie des Sciences, Paris, Series II, 306 : 367-372.

Karakitsios, V., \& Koletti, L., 1992. Critical revision of the age of the basal Vigla Limestones (Ionian Zone, Western Greece) based on Nannoplankton and Calpionellids, with Paleogeographical conse- 
quences, Proceedings of the fourth International Nannoplankton Association Conference (Prague, 1991) (eds. B. Hamersmid and J. Young), pp. 165-177, Knihovnika Zemniho Plynu a Nafty, 14a.

Karakitsios, V., \& Tsaila, - Monopolis, S., 1988. Donnees nouvelles sur les niveaux superieur (Lias inferieurmoyen) des Calcaires de Pantokrator (zone ionienne moyenne, Epire, Grece continenale), Description des Calcaires de Louros, Revue de Micropaleontologie, $31:$ 49-55.

Karakitsios, V., Tsikos, H., Van Breugel, Y., Bakopoulos, I., Koletti, L., 2004. Cretaceous oceanic anoxic events in western continental Greece, Bulletin Geol. Soc. Greece, 34: 846-855.

Laubscher, H.P. \& Bernoulli, D. (1977). Mediterranean and Tethys, In: The ocean basins and margins, Vol. $4 A$, The eastern Mediterranean (eds A.E.M. Nairn, W.H. Kanes, and F.G. Stehli), pp. 1-28, New York: Plenum Press.

McCrea, J.M. (1950). On the isotopic chemistry of carbonates and a paleotemperature scale, J. Chem. Phys., 16(6): 849-857.

Neumann, P. \& Zacher, W. (2004). The Cretaceous sedimentary history of the Pindos basin (Greece), Int. J. Eart Sci (Geol. Rundsch.), 93: 119131.

Pedersen, T.F. \& Calvert, S.E. (1990). Anoxia vs. productivity: what controls the formation of organic-carbon-rich sediments and sedimentary rocks?, American Association of Petroleum Geologists, Bulletin, 74: 454-466.

Richter, D., Muller, C., Mihm, A., Risch, H. (1996). Die Flysch-zonen Griechenlands. XII. Das Bootikum und seine Flysche im Bereich des Iti-Parnass-Elikon-Gebirges, des nor- dwestlichen Kallidromon-Gebirges und des sudwestlichen OthrysGebirges (Mittelgriechenland), Neues Jahrb. Geol. Palaeont. Abh., 201(3): 367-409.

Rigakis, N. \& Karakitsios, V. (1998). The source rock horizons of the Ionian Basin (NW Greece), Marine and Petrolem Geology, 15: 593-617.

Robertson, A.H.F., Clift, P.D., Degnan, P.J., Jones, G. (1991). Palaeogeographic and palaeotectonic evolution of the Eastern Mediterranean Neotethys, Palaeogeogr. Palaeoclimatol. Plaeoecol., 87: 289-343.

Stampfli, G.M. (2000). Tethyan Oceans, In: Bozkurt, E., Winchester, J.A., Piper, J.D.A. (eds.) Tectonics and magmatism in Turkey and the surrounding area, Geol. Soc. Lond. Sp. Publ., 173: 1-23.

Suess, E., Kulm, L.D., Killingley, J.S. (1987). Coastal upwelling and a history of organic-rich mudstone deposition off Peru, In: Brooks, J. \& Fleet, A.J. (eds.) Marine Petroleum Source Rocks, Geological Society of London special publ. No. 26, 181-197.

Tsikos, H., Karakitsios, V., Bombardiere, L., Van Breugel., Y., SinningheDamste, J., Schouten, S., Farrimond, P., Tyson, R.V., Jenkyns, H.C. (2003). The Oceanic Anoxic Event (OAE) 1b in the Ionian Basin, NW Greece: Organic geochemical evidence, Abstract, Mesozoic paleoceanography, SGF, 49-50.

Tsikos, H., Karakitsios, V., Breugel, Y., Walswarth-Bell, B., Bombardiere, L., Petrizzo, M.R., Sinninghe Damste, J.S., Schouten, S., Erba, E., Premoli Silva, I., Farrimond, P., Tyson, R.V., Jenkyns, H.C. (2004). Organic-carbon deposition in the Cretaceous of the Ionian Basin, NW Greece: 
the Paquier Event (OAE1b) revisited, Geol. Mag., 141(4): 401-416.

Tyson, R.V. (1987). The genesis and

palynofacies characteristics of marine petroleum source rocks, In: Brooks, J. \& Fleet, A.J. (eds.) Marine Petroleum Source Rocks, Geological Society of London special publ. No. 26, 47-67.

Tyson, R.V. (2001). Sedimentation rate, dilution, preservation and total organic carbon; some results of a modeling study, Organic Geochemistry, 32: 333-339.

Tyson, R.V. (2005). The "productivi- ty versus preservation" controversy: cause, flaws and resolution, In: Harris, N.B. (ed.) The deposition of organic-carbon-rich sediments: models, mechanisms, and consequences, SEPM special publication No. 82, 17-33.

Urey, H.C., Lowenstan, M.A., Epstein, S., McKinney, C.R., 1951. Measurements of paleotemperature of the Upper Cretaceous of England, Denmark and the Southeastern United States, Geological Society of America Bulletin, 62: 399-416. 